\title{
医薬錠剤における表面吸着水の水素結合状態と粒子間結合力との関係
}

\author{
伊藤武利, $*, a, b$ 神谷秀博 $a$
}

\section{Relationship between Hydrogen-bond Conditions of Surface Adsorbed Water and Interparticle Binding Force on Pharmaceutical Tablets}

\author{
Taketoshi Ito ${ }^{*, a, b}$ and Hidehiro Kamiya ${ }^{a}$ \\ ${ }^{a}$ Graduate School of Bio-Applications and System Engineering, Tokyo University of Agriculture and Technology;

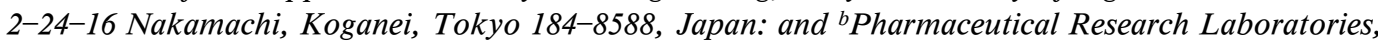 \\ Lion Corporation; 100 Tajima, Odawara, Kanagawa 256-0811, Japan.
}

(Received March 7, 2017; Accepted May 29, 2017)

\begin{abstract}
Influence of water contents to the pharmaceutical tablet strength is known empirically, and participation of hydrogen bonding force among adsorbed water molecules has been presumed. However, the detailed mechanisms of hydrogen bonding phenomena have not been reported. In this study, the hydrogen bonds states of the surface adsorbed waters on the excipient particles of the tablets were focused upon, and the relationship to the interparticle binding force determined by the Rumpf equation was discussed using a near-infrared spectroscopy (NIR). As for the results, NIR peaks of OH groups of surface water were shifted by a humidity change, and the degrees of the peak shifts correlated to interparticle binding force.
\end{abstract}

Key words — tablet; surface adsorbed water; hydrogen bond; binding force; near infra-red; Rumpf equation

\section{緒 言}

医薬品分野においては，近年，水なしで服用可能 な口腔内崩壊錠が注目されている， 口腔内崩壊錠と は口中で噛み砕いたり唾液のみで溶かして服用でき る錠剂で，外出先など水がなくても服用でき，水で 服用する通常の錠剤 (一般錠) や粉薬が苦手な患者 にも広く受け入れられており，その服用性メリット から急速に研究開発がなされている. ${ }^{1)}$ しかし，一 般に錠剂強度と水中崩壊性は相反し，特に口中での 速崩壊性を重視する口腔内崩壊錠では錠剤強度が不 足し易く，製造性やハンドリング性に課題が生じる 場合がある。

錠剂強度に影響する因子としては，錠剤を構成す る粒子間のファンデルワールスカや水素結合，疎水 結合, 静電引力, 液架橋力といつた化学的因子, 空 隙率や粒子形状，接触面積，接触点固結といった物 理的因子等が挙げられ，添加剤の種類によって錠剤

$a$ 東京農工大学大学院生物システム応用科学府, $b$ ライ オン株式会社研究開発本部薬品研究所

*e-mail: itotake@lion.co.jp
強度は異なる，一方，同一組成の錠剂においては錠 剂強度に水分が影響することも経験的に知られてお り，1 個粒子間の粒子間力としては結合エネルギー が比較的大きい水素結合の影響が大きいと考えられ ている. 2) また，添加剤粒子の表面自由エネルギー なども種々検討されている3)が，錠剤強度とはかな らずしも高い相関があるわけではなく，製剤設計の 因子としては十分ではない.

そこで本研究では, 高強度で速崩壊性を有する次 世代の口腔内崩壊錠の製剂設計に有用な新たな因子 を見い出すべく，錠剤を構成する代表的な添加剤粒 子の表面吸着水の水素結合状態に着目した．錠剤強 度には粒子径や空隙率の違いによる粒子接触点数の 影響もあるため，錠剂強度から粒子接触点の粒子間 力を Rumpf の式より算出し，水素結合の状態評価 に有利な近赤外分光法（near-infrared spectroscopy; NIR）により求めた水素結合状態のほか, 吸着水量 や濡れ性との関係を考察した.

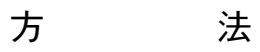

1. 原料及び粉体物性 実験に用いた医薬向け の代表的な添加剤とそのメジアン径， $\mathrm{D}_{50}[\mu \mathrm{m}]$, 
Table 1. Excipient Particles Properties

\begin{tabular}{c|c|c|c}
\hline \hline Diluents & $\begin{array}{c}\text { Median } \\
\text { diameter } \\
\mathrm{D}_{50}[\mu \mathrm{m}]\end{array}$ & $\begin{array}{c}\text { Water content } \\
{\left[\text { after } 120^{\circ} \mathrm{C} 18 \mathrm{~h}\right)}\end{array}$ & $\begin{array}{c}\text { Particle shape } \\
\text { Massive }[\mathrm{M}] \\
\text { Fibrous }[\mathrm{F}]\end{array}$ \\
\hline $\begin{array}{c}\text { Crystalline cellulose } \\
(\mathrm{CC})\end{array}$ & 73 & 3.4 & $\mathrm{~F}$ \\
\hline $\begin{array}{c}\text { Low-substituted } \\
\text { hydroxypropylcel- } \\
\text { lulose (L-HPC) }\end{array}$ & 61 & 2.8 & $\mathrm{~F}$ \\
\hline $\begin{array}{c}\text { Hydroxypropyl } \\
\text { cellulose (HPC) }\end{array}$ & 60 & 1.5 & $\mathrm{~F}$ \\
\hline $\begin{array}{c}\text { Polyvinylpolypyr- } \\
\text { rolidone cross- } \\
\text { linked (CP) }\end{array}$ & 83 & 3.9 & $\mathrm{M}$ \\
\hline $\begin{array}{c}\text { Polyvinylpolypyr- } \\
\text { rolidone (PVP) }\end{array}$ & 150 & 5.3 & $\mathrm{M}$ \\
\hline Mannitol (Man) & 50 & 0.05 & $\mathrm{M}$ \\
\hline $\begin{array}{c}\text { Lactose (Lac) } \\
\text { Corn starch (CS) }\end{array}$ & 48 & 1.2 & $\mathrm{M}$ \\
\hline $\begin{array}{c}\text { Anhydrous dibasic } \\
\text { calcium phosphate } \\
\text { (CaP) }\end{array}$ & 82 & 6.3 & $\mathrm{M}$ \\
\hline $\begin{array}{c}\text { Calcium carbonate } \\
\text { (CaC) }\end{array}$ & 10 & 0.05 & $\mathrm{M}$ \\
\hline
\end{tabular}

水分量 [mass\%] t Table 1 に, 粒子の外観を Fig. 1 にまとめた，有機系添加剤として，結晶セルロース [crystalline cellulose; CC : 旭化成ケミカルズ (株) (東京), PH-101]，低置換度ヒドロキシプロピルセ ルロース [low-substituted hydroxypropylcellulose; L-HPC：信越化学工業(株) (東京), LH-21], 七 ドロキシプロピルセルロース [HPC：日本曹達(株) (東京), HPC-SSL], クロスポビドン [crospovidone; CP : BASF SE (Ludwigshafen), タイプA], ポリビニルピロリドン [ polyvinylpyrrolidone; PVP：(株) 日本触媒（大阪），K90]，コーンスター 于 [corn starch; CS : 松谷化学工業 (株) (伊丹)], D- マンニトール [D-mannitol; Man : Roquette Corp. (Lestrem), ペアリトール 50C, $\beta$ 形], 乳糖 水和物 [ lactose; Lac：DEF Pharma (Goch), Pharmatose 200M]，無機系添加剤として，無水リ ン酸水素カルシウム [anhydrous dibasic calcium phosphate; $\mathrm{CaP}$ : 協和化学工業（株）（坂出）, $\mathrm{GSH}$, 炭酸カルシウム [calcium carbonate; $\mathrm{CaC}$ : 白石カルシウム (株)（大阪）］を用いた。これらは すべて第十六改正日本薬局方又は薬品添加物規格 2013 に適合する市販品を用い，名称の表記も両規
格に準じた.

メジアン径は Beckman Coulter (Indianapolis) のレーザー散乱式粒度分布測定装置 LS13 320 に, 気流中での粒子分散を目的としたトルネードドライ パウダーサンプルモジュールを装着し，気流中での 粒子径分布をオートモードにて測定した。物理吸着 による水分量は, $25^{\circ} \mathrm{C}, 75 \% \mathrm{RH}$ の空調恒温室で 18 時間調湿後の質量と, 大気中， $120^{\circ} \mathrm{C}, 18 \mathrm{~h}$ 乾燥 した直後に測定した質量の質量減少から求めた。

2. 錠剂の空陌率錠剂の空隙率 $\varepsilon$ は, Micromeritics Instrument（Norcross）のガスピクノ メーター（Multivolume Pycnometer 1305）にてへ リウムを用いて求めた錠剤の平均真密度, $\rho_{\mathrm{p}}[\mathrm{g} /$ $\left.\mathrm{cm}^{3}\right]$ と, 錠剤の直径，厚みの実測值から求めた錠 剤の見掛け体積， $\mathrm{V}_{\mathrm{tab}}\left[\mathrm{cm}^{3}\right]$ を用い，Eq. (1)によ り求めた。 $\mathrm{W}_{\mathrm{tab}}$ は錠剤質量 $[\mathrm{g}]$ である。なお，錠 剂の空隙率は 6 個の錠剤について得られた值の平均 值を用いた。

錠剤の空隙率, $\varepsilon=1-\frac{\mathrm{W}_{\mathrm{tab}}}{\mathrm{V}_{\mathrm{tab}} \cdot \rho_{\mathrm{p}}}$

3. 添加剤粒子の水に対する濡れ性 添加剂粒 子の水に対する濡れ性はホソカワミクロン（株）（枚 方）の Peneto Analyzer PNT-N を用い，測定セル に添加剤粉体を充填した後, $20^{\circ} \mathrm{C}$ の水に浸漬して 粉体層に浸透した水の重量変化を経時的に測定し た。浸透水量 $\mathrm{W}_{\mathrm{L}}$ の 2 乗と浸透時間 $\mathrm{t}$ のグラフよ り，初期の安定した勾配から浸透速度係数 $\mathrm{W}_{\mathrm{L}}^{2} / \mathrm{t}$ を 求め, Washburn の式4)より導かれる Eq. (2) から結 晶セルロース（CC）を基準とした $\cos \theta_{\mathrm{t}} / \cos \theta_{0}$ を 算出した.

$$
\frac{\cos \theta_{\mathrm{t}}}{\cos \theta_{0}}=\frac{\left(\mathrm{W}_{\mathrm{Lt}}^{2} / \mathrm{t}_{\mathrm{t}}\right) \cdot \varepsilon_{0}^{2} \cdot \mathrm{r}_{\mathrm{p} 0}}{\left(\mathrm{~W}_{\mathrm{L} 0}^{2} / \mathrm{t}_{0}\right) \cdot \varepsilon_{\mathrm{t}}^{2} \cdot \mathrm{r}_{\mathrm{pt}}}
$$

ここで， $\theta$ は水に対する接触角 $\left[{ }^{\circ}\right], \varepsilon$ は粉体層 の空隙率， $\mathrm{W}_{\mathrm{L}}$ は粉体層に浸透した水の重量 $[\mathrm{g}]$, $\mathrm{r}$ は各添加剂の粒子径 $[\mu \mathrm{m}], \mathrm{t}$ は粉体層に浸透し た水の浸透時間 [s] であり，添え字の 0 は対照物 質として用いた結晶セルロース（CC）の值， $\mathrm{t}$ は 各添加剤の值を示す。

なお，測定セル（半径 $18 \mathrm{~mm}$ ）には添加剤約 $5 \mathrm{~g}$ を充填後, $639 \mathrm{~g}$ の錘で圧縮し，専用のタッピング 装置を用いて $18 \mathrm{~mm}$ のストロークで 300 回タッピ ングした，次に，粉体層の高さを測定して見掛け体 積を求め, 各添加剤の真密度の值から空隙率 $\varepsilon$ を算 


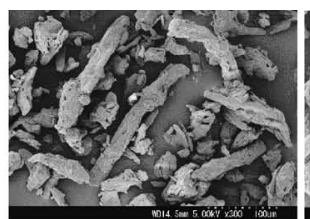

CC

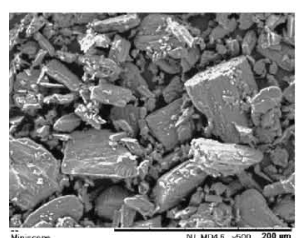

Man

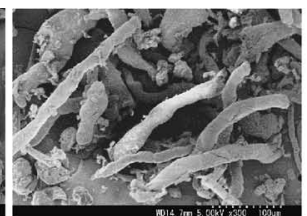

L-HPC

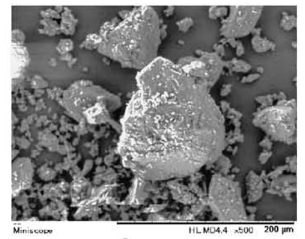

Lac

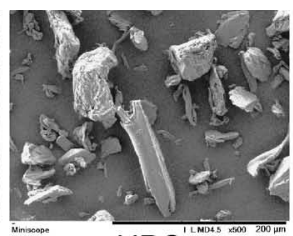

$\mathrm{HPC}$

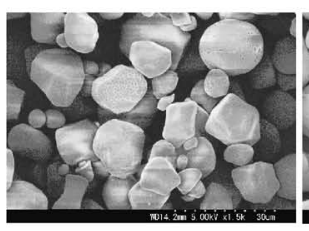

CS

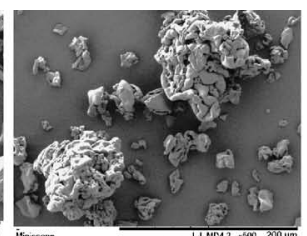

$\mathrm{CP}$

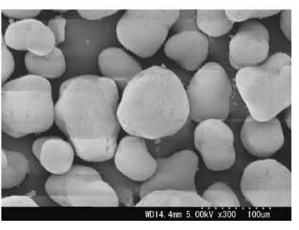

CaP

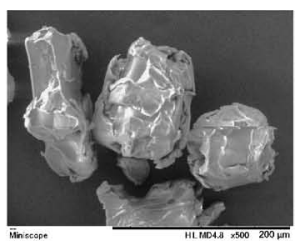

PVP

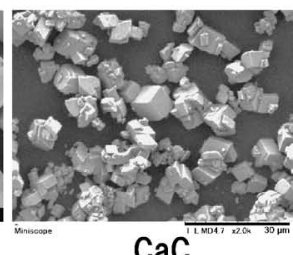

$\mathrm{CaC}$

Fig. 1. SEM Images of Each Excipient Particles

出した．測定は 2 回行い, その平均値を用いた.

\section{4. 打錠 (株) 菊水製作所（京都）の単発式打} 錠機 CRUX 03L 型を用い， あらかじめ $25^{\circ} \mathrm{C} ， 75 \%$ $\mathrm{RH}, 18 \mathrm{~h}$ 調湿した Table 1 の 10 種の添加剂を各々 単独で打錠した。打錠時の粉末充填量（錠剂重量） は $350 \mathrm{mg}$, 錠剤径は $11 \mathrm{~mm}$ の平錠とし, 打錠圧 $1.3 \mathrm{kN}$ にて, $25^{\circ} \mathrm{C}, 75 \% \mathrm{RH}$ の環境下で打錠した. このとき, 錠剤厚みは 3-4 mm となり, 錠剤径, 錠 剂厚みの実測值を, 以下の錠剤強度算出に用いた. なお，錠剤径，錠剂厚みは 6 個の錠剤について得ら れた值の平均值を用いた。

\section{5. 錠剤強度及び粒子間結合力 ジャパンマシ} ナリー(株)（東京）の単軸圧縮強度試験機 Pharma Test を用い, 錠剤の直径方向に加重をかけて破断 時の加重を測定し, Eq. (3)より 錠剂強度（単軸引 張強度, St）を求めた。

錠剂強度（単軸引張強度） $\mathrm{S}_{\mathrm{t}}=2 \mathrm{H} / \pi \mathrm{DL}$

ここで, $\mathrm{H}$ は破断時の荷重 $[\mathrm{N}], \mathrm{D}$ は錠剤の直 径 $[\mathrm{mm}], \mathrm{L}$ は錠剤の厚み $[\mathrm{mm}]$ である.

また, Rumpfの式5) Eq. (4)により 1 個粒子間の 粒子間結合力, $\Sigma$ を求めた.

粒子間結合力, $\Sigma=\mathrm{S}_{\mathrm{t}} \varepsilon \mathrm{d}_{\mathrm{p}}^{2} /(1-\varepsilon)$

ここで, $\varepsilon$ は錠剤の空隙率, $\mathrm{d}_{\mathrm{p}}$ は粒子径 $[\mu \mathrm{m}]$ である.なお, 錠剤強度, 錠剤の空隙率は 6 点の平 均値を用いた。

6. 近赤外分光分析 (NIR) 各添加剂をWet, Dry と定義した次の 2 条件にて調湿した. Wet 条件 は $25^{\circ} \mathrm{C}, 75 \% \mathrm{RH}$ の空調恒温室にて $18 \mathrm{~h}$ 保管し, Dry 条件は乾燥機内で, 大気中, $120^{\circ} \mathrm{C}, 18 \mathrm{~h}$ 乾燥 した. Wet 条件は打錠時と同じ温度湿度条件であ
る. 両条件とも，その雰囲気のままバイアル瓶に密 封し, バイアル瓶のまま近赤外分光分析に供した.

近赤外分光分析は Thermo Fisher Scientific （Waltham）の NICOLET NEXUS 470 FT-IR を用 い, 拡散反射法, 波数分解能 $2 \mathrm{~cm}^{-1}$, 積算 32 回に て測定した。解析ソフトは Thermo Electron Scientific Instruments Corporation (Fitchburg)の OMNIC ver.6.2 を用い, オートモードでピーク值の解析を 行つた.

\section{結果及び考察}

1. 添加剤の水分量, 表面親疎水性の影響 各 添加剂が打錠時の温度湿度 $\left(25^{\circ} \mathrm{C}, 75 \% \mathrm{RH}\right)$ で保 持している水分量（Table 1) と錠剤強度の関係を Fig. 2 に示した. また, Rumpf の式を用いて求め た粒子間力， $\Sigma$ との関係を Fig. 3 に示した. なお,

Table 1 の各添加剂の水分量と添加剂を単独で打錠 成型し測定した水分量はほぼ同様の值で，打錠によ る水分量の変化はなかった.

Figures 2, 3 とも特に相関はみられず, 単に物理 吸着水の水分量では粒子間力との関係を説明できな いと考えられた。粒子形状は Fig. 1 の外観から塊 状, 繊維状に大別して示したが, 粒子形状の影響も みられなかった。

次に, 添加剤粒子表面の親疎水性が錠剤強度と粒 子間結合力に与える影響について検討した。既 報6-8)において, シリカ粒子を表面改質により疎水 化すると高湿度下での液架橋力が低下し, 粒子間付 着力も低下するという報告はあるものの, 医薬錠剤 に用いられる添加剤はいずれもシリカと同程度又は 


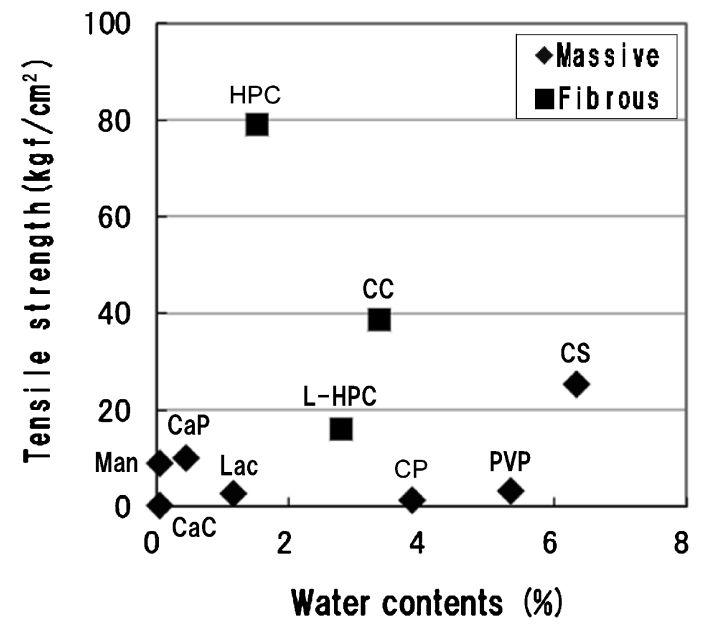

Fig. 2. Relationship between Water Contents and Tensile Strength of Tablets

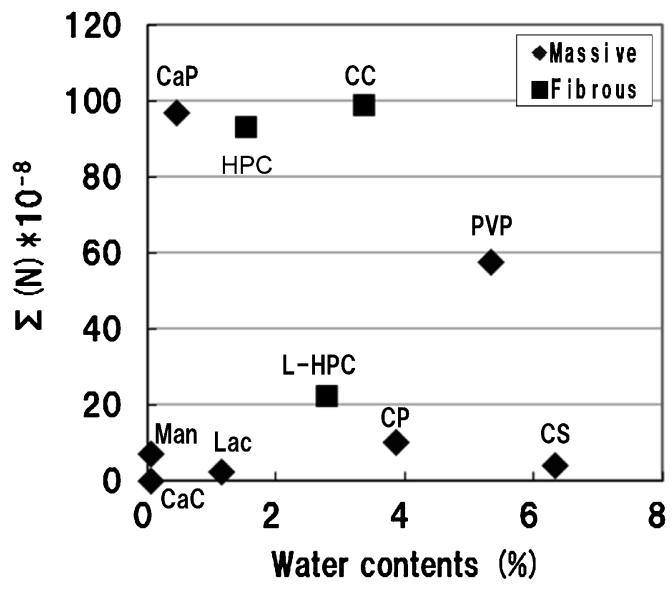

Fig. 3. Relationship between Water Contents and Interparticle Binding Force, $\Sigma$ of Excipient Particles

それ以上に親水的と考えられる，今回用いた添加剂 の表面親疎水性は，結晶セルロースを対照とした水 に対する相対的な濡れ性として，Peneto Analyzer を用いて Eq. (2)にて評価し，錠剤強度，粒子接触 点の粒子間力 $\Sigma$ の関係を Figs. 4,5 に示した.いず れの図も相関性は弱く，この範囲の添加剂表面の親 疎水性の違いでは錠剂強度や粒子間力を十分説明で きないと考えられた。なお，Peneto Analyzerでは 粉体層への水の浸透速度を測定するため，水への溶 解速度が速い粉体 (HPC, PVP, Lac) や粉体層の 充填を一定に調整できなかつた粉体 $(\mathrm{CaC})$ につい ては解析可能なデー夕を取得できなかつたため除外 した.

2. 表面吸着水の影響 ここまでの検討にて, 添加剂の水分量や表面親疎水性などのマクロな物性

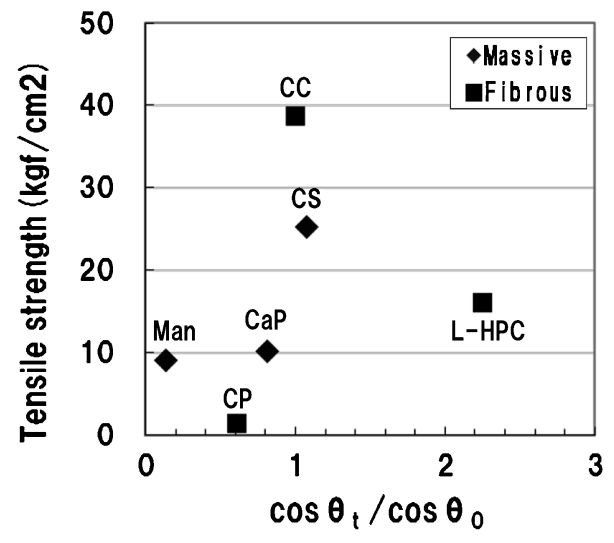

Fig. 4. Relationship between Wettability of Excipient Particles and Tensile Strength of Tablets

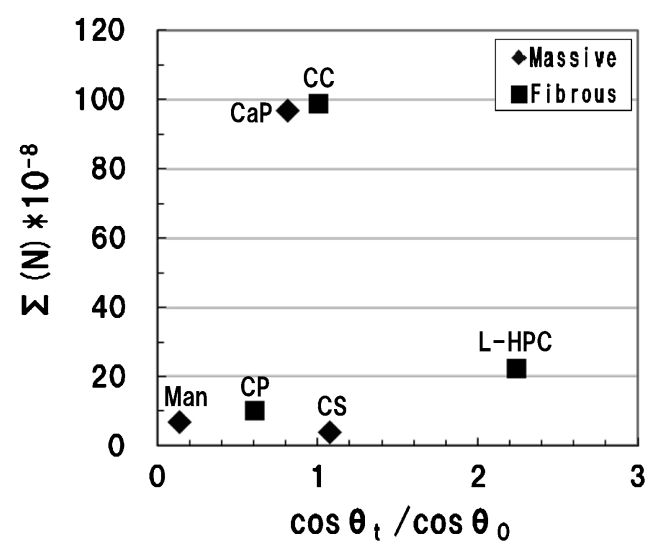

Fig. 5. Relationship Wettability and Interparticle Binding Force, $\Sigma$ of Excipient Particles

が粒子間結合力や錠剤強度に与える影響はみられな かった。一方，医薬添加剤では水素結合状態といっ たミクロな表面物性と錠剤強度との関係についての 詳細な報告はない，そこで本報では，錠剤を構成す る添加剂粒子の表面吸着水の水素結合状態に着目 し，錠剤強度や粒子間力との関連を NIR を用いて 検討した.

竹内ら ${ }^{9,10)}$ は, 水は気相から液相, 固相と変化す るにつれて NIR では約 $300 \mathrm{~cm}^{-1}$ 程度のレッドシフ トが起き化学状態が変化することから，無機酸化物 の吸着水の水素結合状態についてさらに詳細な解析 を行い，吸着水の水酸基の NIR ピークのうち，波 数が小さいピークは水素結合の寄与が大きい水分子 を，波数が大きいピークは水素結合の寄与が小さい 水分子を反映しているとした.

そこで，表面吸着水の水素結合状態は温度湿度に 影響されると予想されたことから，その状態を制御 


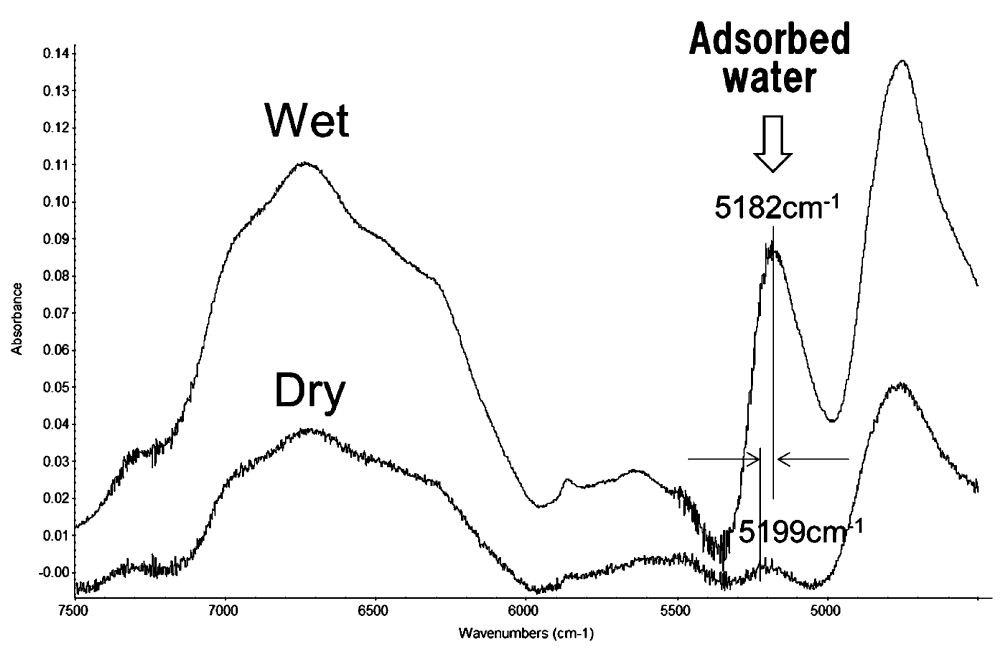

Fig. 6. NIR Spectrum of CC in Dry and Wet Conditions

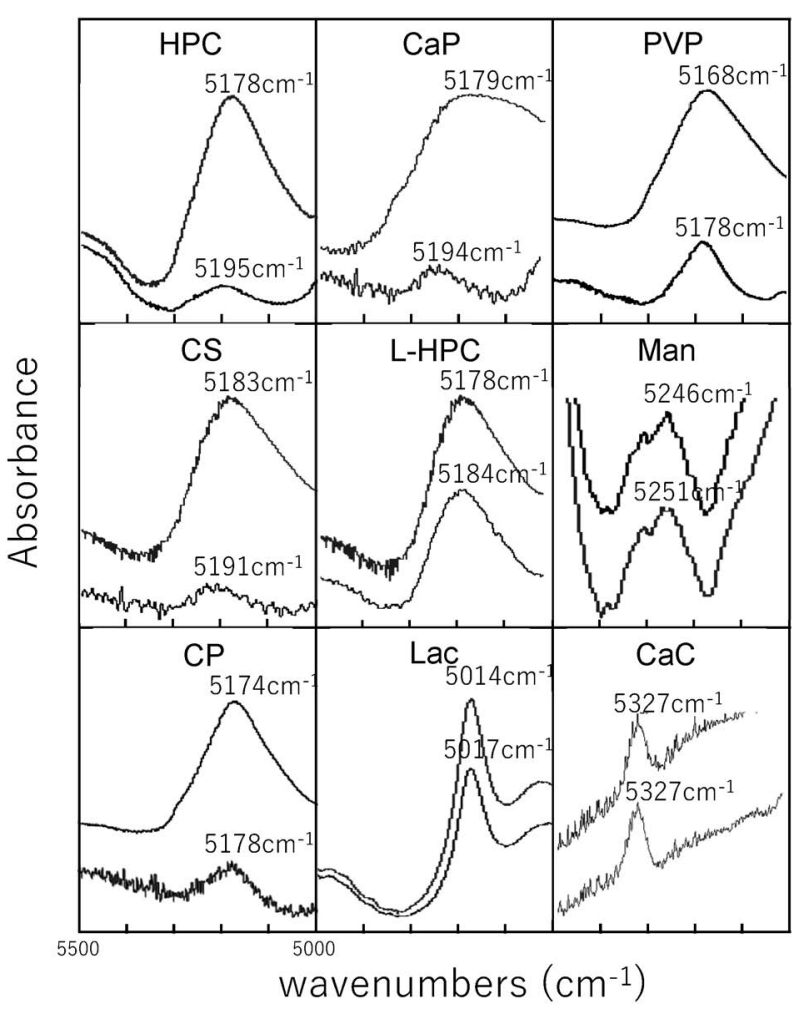

Fig. 7. NIR Spectrum $\left(5500-5000 \mathrm{~cm}^{-1}\right)$ of Each Excipient Upper and under spectrums show wet and dry conditions.

するため，各添加剤粒子を前述の Wet, Dry の 2 条 件にて調湿し，NIR 測定を行った。 $120^{\circ} \mathrm{C}, 18 \mathrm{~h} の$ Dry 条件においては，いずれの添加剤も物理吸着水 がほぼ除去され，少量の化学吸着水が残存した状態 になっていると考えられる. Figure 6 に一例として CC の NIR スペクトルを示した。水酸基のピーク は Dry 条件では $5199 \mathrm{~cm}^{-1}$ ，Wet 条件では 5182 $\mathrm{cm}^{-1}$ に観察された。 Figure 7 には本研究で用いた

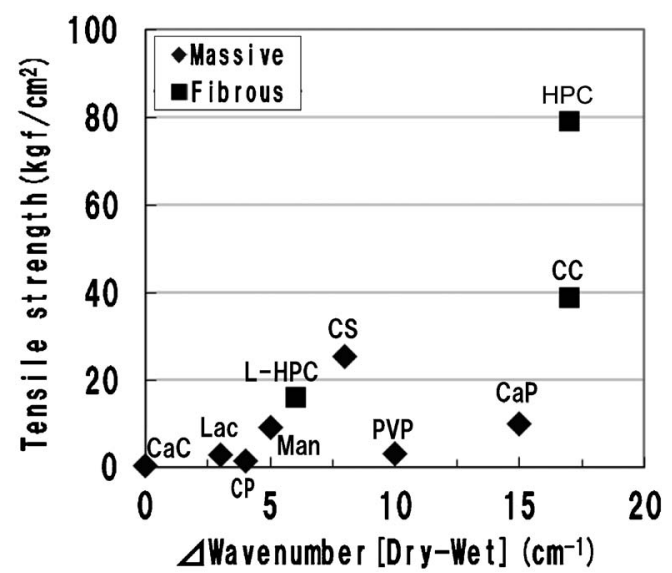

Fig. 8. Relationship between $\Delta$ Wavenumber and Tensile Strength

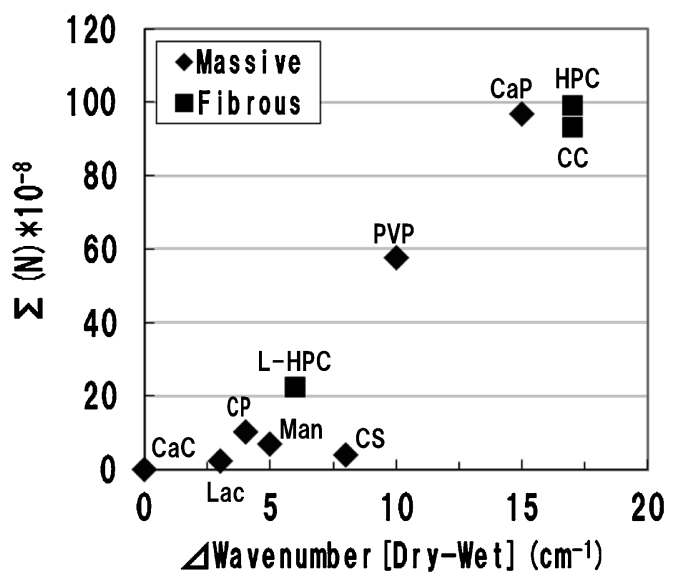

Fig. 9. Relationship between $\Delta$ Wavenumber and $\Sigma$ 
すべての添加剤の Wet, Dry 条件での NIR スペク トルを示した，Man, $\mathrm{CaC}$ について，Table 1 に 示したように吸着水量そのものが少ない（0.05 mass％）ため，吸着水を十分に観察できていない 可能性は考えられるが，他の添加剂は吸着水の水酸 基を反映したものと考える.

添加剤の種類によって吸着水の水酸基のピーク位 置は若干異なるものの，いずれの添加剤においても 5400-5100 $\mathrm{cm}^{-1}$ の水分子のピーク（逆対称伸縮と 変角振動の結合音）は Wet 条件では Dry 条件に比 べ低波数側にシフトした．前述の竹内らの知見に基 づけば, ${ }^{9,10)}$ このようなピークシフトは吸着水の水 素結合状態の差異を反映し, Dry $\rightarrow$ Wet でのピーク シフトが大きいものほど水素結合状態の変化割合も 大きいと考え，この変化量を Dry $\rightarrow$ Wet でのピーク シフト幅, $\Delta$ wavenumber とした。添加剤の結晶性 等によって表面のエピタキシャルな影響は異なり， $120^{\circ} \mathrm{C}, 18 \mathrm{~h}$ で残存する表面近傍の化学吸着水はそ の影響を強く受けている一方， $25^{\circ} \mathrm{C} ， 75 \% \mathrm{RH}$ での 吸着水は多層に吸着している物理吸着水と考えら れ，これらに対する添加剤表面の影響の強弱や，添 加剂と第 1 層吸着水との化学吸着状態など水素結合 様式の違いが $\Delta$ wavenumber に現れていると推察す る.

そこで, $\Delta$ wavenumber と添加剂単独錠の錠剂強 度，粒子間結合力との関係を検討した。添加剤単独 錠は Wet 条件にて打錠したものである。その結果,

Fig. 8 に示したように $\Delta$ wavenumber と錠剤強度と の間には十分な相関はみられず，例えば HPC と CC とは同等の $\Delta$ wavenumber を示したが錠剤強度 は大きく異なった。これは，なるべく粒子径の近い グレードを選定したものの，粒子径の違いによる粒 子接触点の総数の違いも影響していると考える。一 方，Fig. 9 に示したように Rumpf の式から求めら れる 1 個粒子間の粒子間力 $\Sigma$ とは（Man, $\mathrm{CaC}$ を 除外したとしても）添加剤の種類や粒子形状によら ず良好な相関がみられ， HPC や $\mathrm{CC}, \mathrm{CaP}$ のように, Dry $\rightarrow$ Wet (吸湿) による吸着水の水素結合状態の 変化割合が大きい添加剤ほど，粒子間力も大きかっ た．粒子形状との関連性はみられなかった。

このメカニズムについては次のように考察した。 HPC など Dry から Wet への吸湿によって水素結合 状態が変化し易い添加剤は，Wet 状態で新たに吸
着した水分子と水素結合できるものと考えられる. このような添加剤では，打錠時に添加剤粒子同士が 圧縮近接される場合にも，近接された添加剤粒子の 吸着水間で新たな水素結合の発生や組み代わりが起 き易く，その結果，粒子間の水素結合が強化され， 粒子間結合力が大きくなっている可能性が考えられ る。これは, 特に錠剤強度の向上が求められている 口腔内崩壊錠等の製剂設計における添加剂選定の重 要因子として活用できる可能性がある.

以上，医薬錠剤を構成する添加剤粒子の表面吸着 水の水素結合状態を NIR を用いて検討した結果, 湿度変化に対する水酸基のピークシフトの程度は添 加剤の種類によって異なり，吸湿によって水素結合 状態が変化し易い添加剂ほど，Rumpf の式から求 める 1 個粒子間の粒子間力 $\Sigma$ が大きく，両者の関 係性が認められた。

利益相反 伊藤武利(ライオン株式会社の社員).

\section{REFERENCES}

1) Ogata K., Takamura N., Kashiwagi S., Hamada R., Kodama H., Arimori K., Jpn. J. Pharm. Health Care Sci., 27, 553-558 (2001).

2) Maekawa H., "Iyakuhin Kaihatsu Kisokoza 10, Seizai kogaku," CHIJIN SHOKAN CO., LTD., 1971, pp. 140-243.

3) Terada K., "50th Funtai gijutsu senmonkoza," The Association of Powder Process Industry and Engineering, 2009, p. 43.

4) Edward W. W., Phys. Rev., 17, 273-283 (1921).

5) Rumpf H., Chem. Ing. Tech., 30, 144-158 (1958).

6) Fuji M., Machida K., Takei T., Watanabe T., Chikazawa M., J. Phys. Chem. B, 102, 87828787 (1998).

7) Fuji M., Machida K., Takei T., Watanabe T., Chikazawa M., Langmuir, 15, 4584-4589 (1999).

8) Fuji M., J. Surface Sci. Soc. Jpn., 22, 46-54 (2001).

9) Takeuchi M., Anpo M., Martra G., Coluccia S., Materials Integration, $\mathbf{1 9}(7), \quad 35-42$ (2006).

10) Takeuchi M., Martra G., Coluccia S., Anpo M., J. Phys. Chem. B, 109, 7387-7391 (2005). 